\title{
The genetic structure of Drosophila subobscura populations from the islands of Majorca and Minorca (Balearic Islands, Spain) based on allozymes and mitochondrial DNA
}

\author{
JOSÉ A. CASTRO*, MISERICÒRDIA RAMON, ANTÒNIA PICORNELL \\ \& ANDRÉS MOYA† \\ Laboratori de Genètica, Departament de Biologia, Facultat de Ciències, Universitat de les Illes Balears, \\ Palma de Mallorca (Balears), Spain and †Institut Cavaniltes de Biodiversitat i Biologia Evolutiva i Departament de Genètica, \\ Universitat de València, Burjassot (València), Spain
}

\begin{abstract}
The genetic structure of seven populations of Drosophila subobscura from different locations on Majorca and Minorca (Balearic Islands, Spain) was studied using two types of markers: allozyme and mitochondrial DNA restriction analyses. Both markers showed congruent results. In the allozyme data, when the Acph-1 locus was excluded from the joint $F_{\mathrm{ST}}$ statistics, only three out of 21 comparisons were statistically significant, lending support to the hypothesis of low genetic differentiation. The mtDNA restriction analyses showed two haplotypes at a high frequency (more than $40 \%$ each), irrespective of the location considered, and a number of endemic haplotypes at very low frequencies (not higher than $2 \%$ each). The analyses of the genetic structure yielded a pattern similar to the allozymes. The cytonuclear disequilibrium analyses showed the difficulty of detecting cytonuclear associations in natural populations because they are mainly transient.
\end{abstract}

Keywords: allozymes, Drosophila subobscura, Majorca, Minorca, mtDNA haplotypes.

\section{Introduction}

Drosophila subobscura is a Palaearctic species of the obscura subgroup of Drosophila, which is endemic throughout Europe (except central and northern Scandinavia) as well as the Middle East, northern Africa and on the Atlantic islands of the Azores, Madeira and the Canaries. Natural populations have been extensively studied during the latter half of this century. Among the genetic traits studied, allozymes (Pinsker et al., 1978; Cabrera et al., 1980; Latorre et al., 1992), which give a uniform allele distribution irrespective of which locus or geographical area is considered, and inversion polymorphisms (Menozzi \& Krimbas, 1992; Orengo \& Prevosti, 1996), which exhibit clear clinal frequency distributions, are particularly relevant. In recent years, mtDNA studies have increased our knowledge of this species. Previous studies on the distribution of mtDNA haplotypes in the Old World populations of $D$. subobscura have shown the presence of two widespread and equally frequent haplotypes, as well as a set of less common haplotypes generally present in never more than a single locality (Afonso et al.,

*Correspondence. E-mail: dbajco0@ps.uib.es

(C) 1999 The Genetical Society of Great Britain.
1990; Latorre et al., 1992; Moya et al., 1993; González et al., 1994; García-Martínez et al., 1998), with the exception of the Canary Islands, where an endemic haplotype is the most frequent. The same distribution pattern has been detected in the New World colonizing populations of D. subobscura (Rozas et al., 1990). It is still an unresolved question which evolutionary processes account for this distribution. Studies concerning the genetic dynamics of the mtDNA and experiments in different species have shown inconclusive results with respect to selection or neutrality, such as for example in D. melanogaster (Kilpatrick \& Rand, 1995), D. pseudoobscura (MacRae \& Anderson, 1988), D. subobscura (Fos et al., 1990), D. pseudoobscura and D. persimilis (Hutter \& Rand, 1995). A shared aspect in most of these experiments is the possible cytonuclear interactions between the mtDNA and the nuclear markers which may affect fitness. The detection of such interactions is difficult, because we do not know which kind of relationship exists or between which nuclear markers it is established. The cytonuclear disequilibria method (Asmussen \& Basten, 1994) could be used to detect such fitness interactions.

The purpose of this work was to determine the genetic structure of natural populations of $D$. subobscura from 
the islands of Majorca and Minorca (Balearic Islands) in relation to allozymic and mtDNA markers. At the same time, we have tried to detect cytonuclear interactions between the mtDNA and some nuclear markers in an attempt to understand the population dynamics of mtDNA haplotypes of this species.

\section{Materials and methods}

We studied approximately 500 isofemale lines of D. subobscura in seven samples from the Balearic Islands: three on the island of Majorca (MA.1, MA.2 and MA.3) and four on Minorca (MI.1, MI.2, MI.3 and MI.4). The three samples from Majorca were collected at the same location, a pine forest near Esporles, in spring and autumn 1992 and in spring 1993. Three of the Minorcan samples were collected in a pine forest from the north of the island in autumn 1994, spring 1995, and spring 1996, and the last one in another pine forest from the south of the island in spring 1996, $20 \mathrm{~km}$ away from the first location. The flies were collected with conventional traps of fermented bananas. Once in the laboratory, females were placed individually into a tube with food and kept in an incubator at $19^{\circ} \mathrm{C}$. When the $F_{1}$ larvae appeared, females were used for allozyme analyses and the offspring were used to determine maternal mitochondrial haplotypes.

\section{Allozyme analysis}

The allozyme analyses were carried out using starch gel electrophoresis as described by Ayala et al. (1972) and Brewer (1970). The following 12 enzymes (13 loci) were analysed in each fly: alcohol dehydrogenase (Adh), octanol dehydrogenase $(O d h)$, superoxide dismutase $(S o d)$, malate dehydrogenase $(M d h-1)$, isocitrate dehydrogenase $(I d h)$, xanthine dehydrogenase $(X d h)$, fumarase (Fum), catalase (Cat), acid phosphatase (Acph-1, Acph-2), phosphoglucomutase (Pgm-1), alkaline phosphatase (Aph-4) and esterase (Est-5). The APH-4 and EST-5 enzymes were only studied in the last two populations from Minorca in an attempt to find allozymes with alleles of intermediate frequencies. Some of these enzymes have a close functional relationship with mitochondrial metabolism (i.e. FUM, MDH-1, IDH). All the enzymes from a single fly were assayed simultaneously, by cutting slices from the starch gel after electrophoresis to reveal the different allozymes in each one. In a few cases slices were lost, which caused slightly variable sample sizes.

\section{Extraction and digestion of $m t D N A$}

An enriched fraction of mtDNA was obtained by the method described by Latorre et al. (1986). This fraction was digested with five restriction enzymes. Three of the enzymes (EcoRI, EcoRV and HindIII) recognize sequences of $6 \mathrm{bp}$, whereas the other two (HpaII and Hae III) sequences of $4 \mathrm{bp}$. These enzymes were selected for their capability of detecting mtDNA polymorphisms (Afonso et al., 1990; Latorre et al., 1992).

The fragments obtained by digestion were separated on horizontal $0.8-2.0 \%$ agarose gels. To determine fragment size, lambda DNA digested with HindIII and lambda DNA double digested with HindIII-EcoRI were used as size standards. After electrophoresis, gels were stained with $0.1 \mu \mathrm{g}$ ethidium bromide $\mathrm{mL}^{-1}$ and visualized with a $260-\mathrm{nm}$ UV light transilluminator.

A mtDNA restriction map was obtained by means of all possible single and double digestions of the mtDNA. The different restriction patterns obtained, using a given enzyme and the haplotypes, were named according to the notation of Latorre et al. $(1986,1992)$.

\section{Statistical analysis}

Allele and genotype frequencies were estimated for each system and population from the allozymic electrophoretic data. Hardy-Weinberg equilibria were tested using the BIOsYs-1 program (Swofford \& Selander, 1989). The Bonferroni procedure was used to correct the deviations in the $\chi^{2}$-test that originated from the number of tests performed (Weir, 1990). Heterogeneity was analysed by the $F$-statistics $\left(F_{\mathrm{IS}}, F_{\mathrm{IT}}, F_{\mathrm{ST}}\right)$ (Wright, 1965). The degree of mtDNA differentiation within and between populations $\left(V_{\mathrm{w}}\right.$ and $\left.V_{\mathrm{b}}\right)$, as well as the degree of population subdivision $\left(N_{\mathrm{ST}}\right)$ were estimated following Lynch \& Crease (1990), with a computer program kindly supplied by the authors. We used Tajima's $D$-test (Tajima, 1989) to test for any departure from neutrality for the mtDNA haplotype distribution in the populations. The cytonuclear interactions were performed following the methodology developed by Asmussen \& Basten (1994), by calculating the cytonuclear disequilibria and considering a diallelic nuclear locus and two cytoplasmic haplotypes.

\section{Results}

Table 1 shows the allele frequencies of the 13 isozyme loci studied in the seven samples. Aph-4 and Est-5 were studied in two of the Minorcan populations. Cat and Acph-2 were only analysed in the Majorcan populations. Most of the enzymes were polymorphic, although some populations had a single fixed genotype; however, interestingly, $X d h$ was monomorphic in all Majorcan population, but not in the Minorcan ones.

Most allozymes were in Hardy-Weinberg equilibrium (those not in equilibrium were mainly in the Minorcan samples). The global $F_{\mathrm{ST}}$ values were significant in all 
Table 1 Allele frequencies of the 13 isozyme loci in the seven samples of Drosophila subobscura

\begin{tabular}{|c|c|c|c|c|c|c|c|c|}
\hline \multirow[b]{2}{*}{ Locus } & \multirow[b]{2}{*}{ Allele } & \multicolumn{7}{|c|}{ Samples } \\
\hline & & MA.1 & MA.2 & MA.3 & MI.1 & MI.2 & MI.3 & MI.4 \\
\hline$A d h$ & $\begin{array}{c}N \\
70 \\
100 \\
110\end{array}$ & $\begin{array}{l}44 \\
0.023 \\
0.966 \\
0.011\end{array}$ & $\begin{array}{r}68 \\
0 \\
1 \\
0\end{array}$ & $\begin{array}{l}100 \\
0 \\
0.975 \\
0.025\end{array}$ & $\begin{array}{l}58 \\
0 \\
0.966 \\
0.034\end{array}$ & $\begin{array}{r}117 \\
0.009 \\
0.983 \\
0.009\end{array}$ & $\begin{array}{l}62 \\
0 \\
0.984 \\
0.016\end{array}$ & $\begin{array}{l}58 \\
0 \\
0.991 \\
0.009\end{array}$ \\
\hline Odh & $\begin{array}{c}N \\
80 \\
100 \\
110\end{array}$ & $\begin{array}{r}29 \\
0 \\
1 \\
0\end{array}$ & $\begin{array}{l}68 \\
0 \\
0.926 \\
0.074\end{array}$ & $\begin{array}{l}100 \\
0 \\
0.945 \\
0.055\end{array}$ & $\begin{array}{l}54 \\
0 \\
0.917 \\
0.083\end{array}$ & $\begin{array}{l}117 \\
0 \\
0.936 \\
0.064\end{array}$ & $\begin{array}{l}62 \\
0 \\
0.903 \\
0.097\end{array}$ & $\begin{array}{l}58 \\
0.017 \\
0.940 \\
0.043\end{array}$ \\
\hline Sod & $\begin{array}{c}N \\
80 \\
100 \\
120\end{array}$ & $\begin{array}{r}44 \\
0 \\
1 \\
0\end{array}$ & $\begin{array}{l}68 \\
0.015 \\
0.971 \\
0.015\end{array}$ & $\begin{array}{l}100 \\
0.005 \\
0.095 \\
0\end{array}$ & $\begin{array}{l}48 \\
0.042 \\
0.958 \\
0\end{array}$ & $\begin{array}{l}118 \\
0.008 \\
0.992 \\
0\end{array}$ & $\begin{array}{l}62 \\
0.016 \\
0.984 \\
0\end{array}$ & $\begin{array}{l}58 \\
0.026 \\
0.974 \\
0\end{array}$ \\
\hline$M d h-1$ & $\begin{array}{c}N \\
70 \\
100 \\
140\end{array}$ & $\begin{array}{l}43 \\
0 \\
0.942 \\
0.058\end{array}$ & $\begin{array}{l}68 \\
0 \\
0.846 \\
0.154\end{array}$ & $\begin{array}{l}98 \\
0.020 \\
0.918 \\
0.061\end{array}$ & $\begin{array}{l}54 \\
0 \\
0.935 \\
0.065\end{array}$ & $\begin{array}{l}117 \\
0 \\
0.915 \\
0.085\end{array}$ & $\begin{array}{l}59 \\
0.136 \\
0.864 \\
0\end{array}$ & $\begin{array}{l}54 \\
0.028 \\
0.944 \\
0.028\end{array}$ \\
\hline$I d h$ & $\begin{array}{c}N \\
90 \\
100 \\
120\end{array}$ & $\begin{array}{l}27 \\
0.204 \\
0.796 \\
0\end{array}$ & $\begin{array}{r}47 \\
0 \\
1 \\
0\end{array}$ & $\begin{array}{r}69 \\
0 \\
1 \\
0\end{array}$ & $\begin{array}{l}58 \\
0.009 \\
0.991 \\
0\end{array}$ & $\begin{array}{r}56 \\
0 \\
1 \\
0\end{array}$ & $\begin{array}{l}49 \\
0.020 \\
0.969 \\
0.010\end{array}$ & $\begin{array}{l}58 \\
0.103 \\
0.897 \\
0\end{array}$ \\
\hline$X d h$ & $\begin{array}{c}N \\
90 \\
100\end{array}$ & $\begin{array}{r}44 \\
0 \\
1\end{array}$ & $\begin{array}{r}68 \\
0 \\
1\end{array}$ & $\begin{array}{r}100 \\
0 \\
1\end{array}$ & $\begin{array}{l}58 \\
0.069 \\
0.931\end{array}$ & $\begin{array}{r}116 \\
0.004 \\
0.996\end{array}$ & $\begin{array}{r}62 \\
0 \\
1\end{array}$ & $\begin{array}{l}57 \\
0.018 \\
0.982\end{array}$ \\
\hline Fum & $\begin{array}{c}N \\
90 \\
100 \\
120 \\
130\end{array}$ & $\begin{array}{r}44 \\
0 \\
1 \\
0 \\
0\end{array}$ & $\begin{array}{l}68 \\
0.029 \\
0.971 \\
0 \\
0\end{array}$ & $\begin{array}{l}100 \\
0.005 \\
0.995 \\
0 \\
0\end{array}$ & $\begin{array}{l}58 \\
0.017 \\
0.957 \\
0.026 \\
0\end{array}$ & $\begin{array}{r}114 \\
0.031 \\
0.956 \\
0.004 \\
0.009\end{array}$ & $\begin{array}{l}62 \\
0.016 \\
0.976 \\
0 \\
0.008\end{array}$ & $\begin{array}{l}57 \\
0.009 \\
0.991 \\
0 \\
0\end{array}$ \\
\hline Cat & $\begin{array}{c}N \\
100 \\
200\end{array}$ & $\begin{array}{l}44 \\
0.852 \\
0.148\end{array}$ & $\begin{array}{l}44 \\
0.705 \\
0.295\end{array}$ & $\begin{array}{l}13 \\
0.885 \\
0.115\end{array}$ & - & - & - & - \\
\hline Acph-1 & $\begin{array}{c}N \\
100 \\
130 \\
200\end{array}$ & $\begin{array}{l}26 \\
0.635 \\
0.192 \\
0.173\end{array}$ & $\begin{array}{l}49 \\
0.694 \\
0.163 \\
0.143\end{array}$ & $\begin{array}{l}79 \\
0.937 \\
0.006 \\
0.057\end{array}$ & $\begin{array}{l}58 \\
0.914 \\
0.086 \\
0\end{array}$ & $\begin{array}{l}97 \\
0.392 \\
0.015 \\
0.593\end{array}$ & $\begin{array}{l}40 \\
0.663 \\
0.162 \\
0.175\end{array}$ & $\begin{array}{l}46 \\
0.783 \\
0.109 \\
0.109\end{array}$ \\
\hline Acph-2 & $\begin{array}{c}N \\
100 \\
200\end{array}$ & $\begin{array}{r}26 \\
1 \\
0\end{array}$ & $\begin{array}{r}49 \\
1 \\
0\end{array}$ & $\begin{array}{l}79 \\
0.962 \\
0.038\end{array}$ & - & - & - & - \\
\hline Pgm-1 & $\begin{array}{c}N \\
90 \\
100 \\
120 \\
140\end{array}$ & $\begin{array}{l}44 \\
0.102 \\
0.864 \\
0.034 \\
0\end{array}$ & $\begin{array}{l}66 \\
0.121 \\
0.864 \\
0.015 \\
0\end{array}$ & $\begin{array}{l}97 \\
0.026 \\
0.923 \\
0.052 \\
0\end{array}$ & $\begin{array}{l}59 \\
0.059 \\
0.898 \\
0.042 \\
0\end{array}$ & $\begin{array}{l}116 \\
0.043 \\
0.927 \\
0.026 \\
0.004\end{array}$ & $\begin{array}{l}62 \\
0.113 \\
0.871 \\
0.016 \\
0\end{array}$ & $\begin{array}{l}58 \\
0.069 \\
0.871 \\
0.060 \\
0\end{array}$ \\
\hline Aph-4 & $\begin{array}{c}N \\
100 \\
200\end{array}$ & - & - & - & - & - & $\begin{array}{l}58 \\
0.931 \\
0.069\end{array}$ & $\begin{array}{l}57 \\
0.886 \\
0.114\end{array}$ \\
\hline Est-5 & $\begin{array}{c}N \\
80 \\
100\end{array}$ & - & - & - & - & - & $\begin{array}{l}60 \\
0.033 \\
0.967\end{array}$ & $\begin{array}{l}58 \\
0.138 \\
0.862\end{array}$ \\
\hline
\end{tabular}

$N$, number of individuals.

(C) The Genetical Society of Great Britain, Heredity, 83, 271-279. 
Table $2 F_{\mathrm{ST}}$ between paired populations of Drosophila subobscura. The $F_{\mathrm{ST}}$ values below the diagonal are for eight systems (without $A c p h-1$ ) and those above the diagonal for the nine systems present in all populations

\begin{tabular}{lrlllllll}
\hline & & \multicolumn{7}{c}{ Samples } \\
\cline { 3 - 8 } Samples & \multicolumn{1}{c}{$N$} & MA.1 & MA.2 & MA.3 & MI.1 & MI.2 & MI.3 & MI.4 \\
\hline MA.1 & 38 & - & 0.024 & $0.060^{* *}$ & $0.048^{* *}$ & $0.074^{* *}$ & 0.022 & 0.014 \\
MA.2 & 63 & $0.038^{*}$ & - & $0.033^{* *}$ & 0.024 & $0.069^{* *}$ & 0.009 & 0.014 \\
MA.3 & 94 & $0.040^{* *}$ & 0.013 & - & 0.009 & $0.152^{* *}$ & $0.038^{* *}$ & 0.019 \\
MI.1 & 56 & 0.034 & 0.011 & 0.007 & - & $0.136^{* *}$ & 0.031 & 0.015 \\
MI.2 & 107 & $0.038^{* *}$ & 0.008 & 0.002 & 0.005 & - & $0.062^{* *}$ & $0.090^{* *}$ \\
MI.3 & 57 & 0.035 & 0.015 & 0.014 & 0.014 & 0.015 & - & 0.013 \\
MI.4 & 56 & 0.011 & 0.018 & 0.012 & 0.010 & 0.013 & 0.013 & - \\
\hline
\end{tabular}

$N$, number of individuals.

The Bonferroni correction was applied to the $F_{\mathrm{ST}}$ calculations.

${ }^{*} P<0.01, * * P<0.001$.

cases, indicating a genetic structure among the samples. Acph-1 was the enzyme that made the greatest contribution to this differentiation, although this was mainly because of sample 2 from Minorca, which clearly exhibited a different proportion of alleles. The total $F_{\text {ST }}$ was 0.075 , but when the analyses were made without Acph-1, this value decreased to 0.030 , which was also significant. For the $F_{\mathrm{ST}}$ between paired populations (Table 2), 10 out of 21 comparisons were significant when Acph- 1 was included (above the diagonal). This proportion decreased to three out of 21 when Acph-1 was not included (below the diagonal). Without Acph-1, the seven samples did not show any clear genetic differentiation.

Figure 1 (bottom) shows the mtDNA cleavage map of the five restriction enzymes, based on the physical mtDNA map of D. yakuba (Clary \& Wolstenholme, 1985). We found 21 polymorphic sites and eight conserved regions. The NADH complex genes were concentrated in nine variable $(43 \%)$ and three conserved (37\%) sites. Latorre et al. (1992) found 69\% and 17\%, respectively.

Table 3 shows the different polymorphic sites which defined every haplotype found in the populations. As in other populations, haplotypes I and II were the most frequent $(92.5 \%)$, with haplotype II being commoner than I. The less common haplotypes accounted for only $7.5 \%$ and, in general, they were unique for each population. Similar results were obtained by González et al. (1994). The relationship between haplotypes I and II and the rare ones is also indicated in Fig. 1, which represents an unrooted phylogenetic tree of the 26 haplotypes of $D$. subobscura mtDNA. Ten haplotypes were derived from haplotype I and 14 from haplotype II, caused by unique mutations in the mtDNA, with the exception of haplotypes XXI, XXII and XXV, which had passed through two mutational steps.
Table 4 shows the mitochondrial DNA differentiation within and between populations, after Lynch \& Crease (1990). Most of the observed variation was concentrated within populations. The total amount of mtDNA polymorphism may be estimated by the average number $\left(V_{\mathrm{w}}\right)$ of substitutions per nucleotide site for random pairs of haplotypes from the same population, plus the average number $\left(V_{\mathrm{b}}\right)$ between populations. In our data, $V_{\mathrm{w}}=0.00498 \pm 0.00415$ and $V_{\mathrm{b}}=-0.00002 \pm 0.00006$. The fraction of the nucleotide variation between populations, $N_{\mathrm{ST}}$, was $-0.004 \pm 0.063$, which was not significantly different from zero.

Tajima's $D$-test (Tajima, 1989) was used to test departures of the mtDNA haplotypic distribution from the neutrality hypothesis. The rationale of the test is that in a panmictic population, under the neutral mutation model, no difference would be expected between the average number of nucleotide differences (i.e. nucleotide

Fig. 1 Top: Unrooted phylogenetic tree for the 26 haplotypes of the Majorcan and Minorcan populations of Drosophila subobscura. The haplotypes are connected in a way that minimizes the total number of necessary site changes. The number of mutational steps is indicated on each branch. Bottom: D. subobscura mtDNA organization based on the genetic map of D. yakuba given by Clary \& Wolstenholme (1985). Conserved sites are shown above and polymorphic sites below the map. Abbreviations for the genes are as follows: srRNA and lrRNA, small and large subunits of ribosomal RNA, respectively; ND1-6, subunits of the NADH dehydrogenase complex; Cytb, cytochrome b; COI-III, subunits of cytochrome oxidase; 8 , ATPase 8 ; A $+\mathrm{T}$, regulatory noncoding region. Each site is named with a letter, for each one of the restriction endonucleases, followed by a number corresponding to a specific restriction site. (d) EcoRI; (k) EcoRV; (e) HaeIII; (h) HpaII and (f) HindIII. 
heterozygosity) and the number of segregating sites. Table 5 gives the estimates of $D$ for each of the seven samples; for the three samples from Majorca, for the samples from Minorca and for the pooled population. No significant departures from neutrality were found in the different samples, nor in the Majorcan population, at the $5 \%$ level, although the Minorcan and the total populations did show a significant negative departure from neutrality, thus indicating that there were excessive numbers of rare haplotypes.
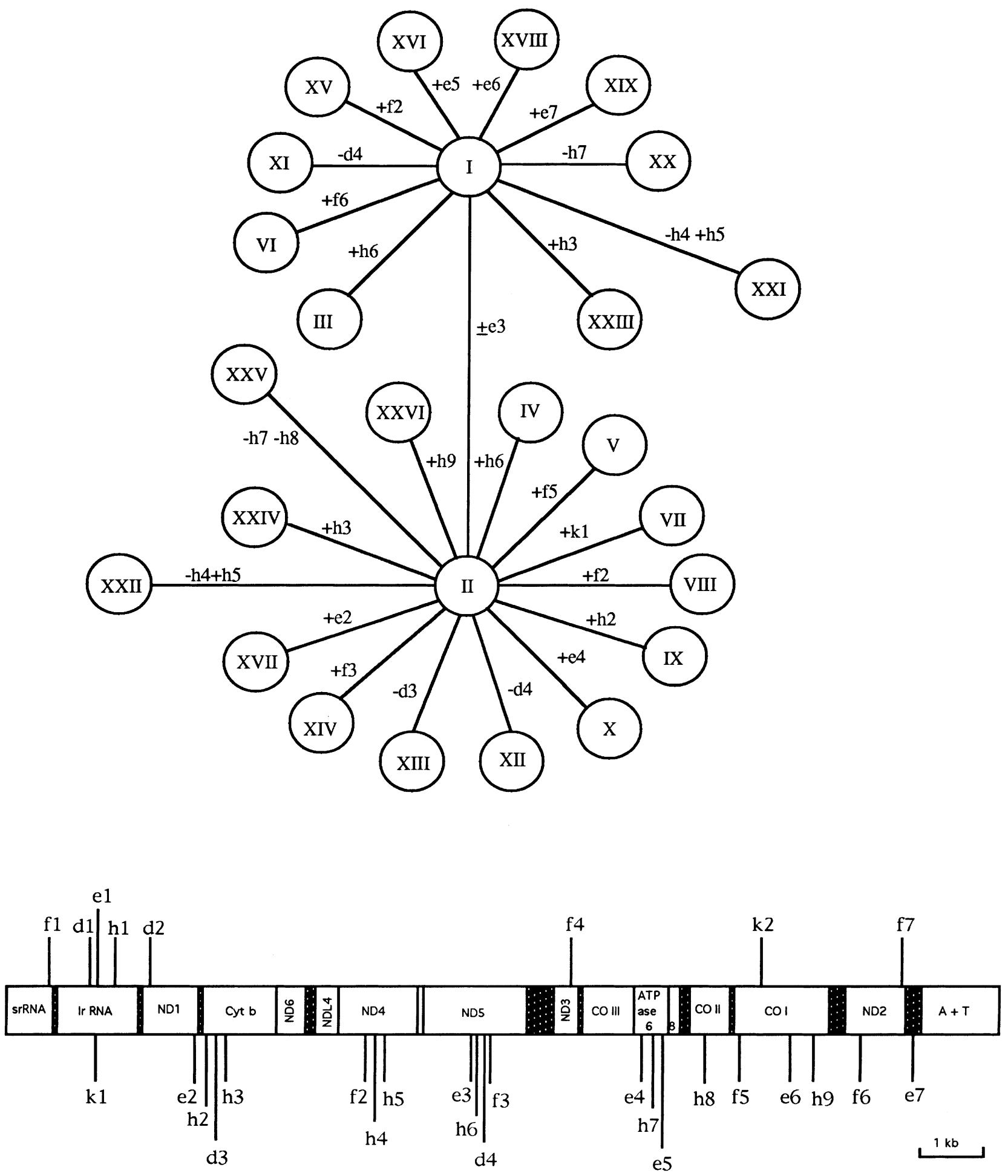

(c) The Genetical Society of Great Britain, Heredity, 83, 271-279. 
Table 3 The different haplotypes defined by the polymorphic sites and the number of isofemale lines showing a given haplotype in the Drosophila subobscura populations sampled from Majorcan (MA) and Minorcan (MI) populations. Each site is named as in the restriction map (Fig. 1, bottom). Presence or absence of a given polymorphic site is indicated by a plus $(+)$ or a minus $(-)$, respectively

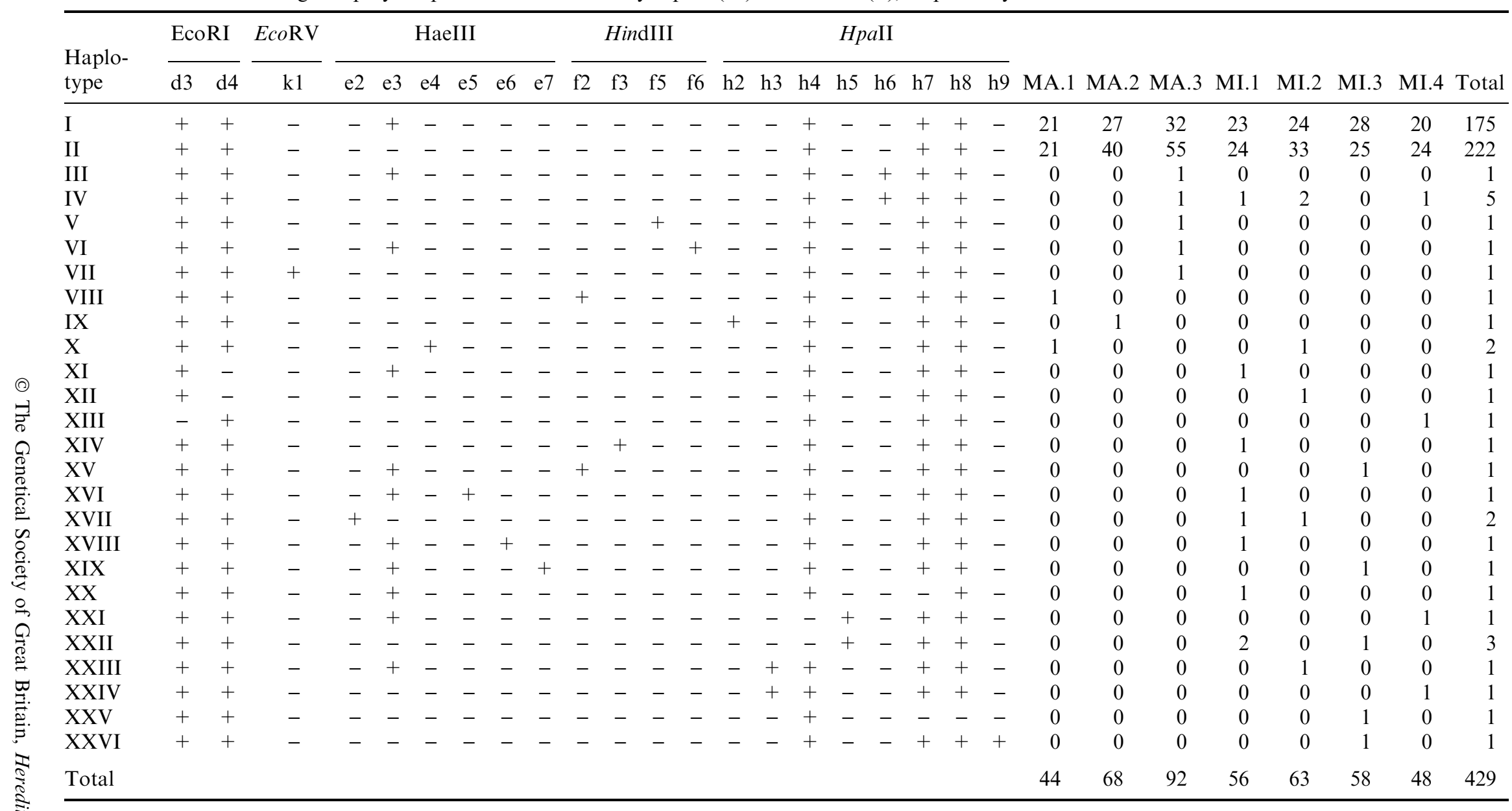


Table 4 Mitochondrial DNA differentiation $\left(\times 10^{-5}\right)$, with standard errors in parentheses, within and between populations of Drosophila subobscura. Values on the main diagonal are the within-population differentiation $\left(V_{\mathrm{w}}\right)$, whereas values above the diagonal are between-populations differentiation $\left(V_{\mathrm{b}}\right)$

\begin{tabular}{|c|c|c|c|c|c|c|c|}
\hline Population & MA.1 & MA.2 & MA.3 & MI.1 & MI.2 & MI.3 & MI.4 \\
\hline MA.1 & $\begin{array}{c}439 \\
(398)\end{array}$ & $\begin{array}{c}-2 \\
(417)\end{array}$ & $\begin{array}{c}2 \\
(389)\end{array}$ & $\begin{array}{c}-7 \\
(278)\end{array}$ & $\begin{array}{c}-3 \\
(348)\end{array}$ & $\begin{array}{c}-7 \\
(340)\end{array}$ & $\begin{array}{c}-7 \\
(347)\end{array}$ \\
\hline MA.2 & & $\begin{array}{c}377 \\
(367)\end{array}$ & $\begin{array}{c}-4 \\
(388)\end{array}$ & $\begin{array}{c}0 \\
(301)\end{array}$ & $\begin{array}{c}-5 \\
(356)\end{array}$ & $\begin{array}{c}4 \\
(376)\end{array}$ & $\begin{array}{c}-5 \\
(365)\end{array}$ \\
\hline MA.3 & & & $\begin{array}{c}422 \\
(366)\end{array}$ & $\begin{array}{c}5 \\
(274)\end{array}$ & $\begin{array}{c}-5 \\
(321)\end{array}$ & $\begin{array}{r}11 \\
(352)\end{array}$ & $\begin{array}{c}-3 \\
(333)\end{array}$ \\
\hline MI.1 & & & & $\begin{array}{c}666 \\
(459)\end{array}$ & $\begin{array}{c}-1 \\
(241)\end{array}$ & $\begin{array}{c}-7 \\
(240)\end{array}$ & $\begin{array}{c}-8 \\
(238)\end{array}$ \\
\hline MI.2 & & & & & $\begin{array}{c}496 \\
(397)\end{array}$ & $\begin{array}{c}5 \\
(309)\end{array}$ & $\begin{array}{c}-6 \\
(297)\end{array}$ \\
\hline MI.3 & & & & & & $\begin{array}{c}558 \\
(424)\end{array}$ & $\begin{array}{c}-4 \\
(307)\end{array}$ \\
\hline MI.4 & & & & & & & $\begin{array}{c}526 \\
(413)\end{array}$ \\
\hline
\end{tabular}

Table 5 Estimates of $D$ and its significance according to Tajima (1989) for populations of Drosophila subobscura

\begin{tabular}{lcrc}
\hline Population & Sample size & \multicolumn{1}{c}{$D$} & Significance \\
\hline MA.1 & 44 & -0.272 & NS \\
MA.2 & 68 & 0.389 & NS \\
MA.3 & 92 & -0.885 & NS \\
MI.1 & 56 & -1.645 & $P<0.10$ \\
MI.2 & 63 & -1.142 & NS \\
MI.3 & 58 & -1.500 & NS \\
MI.4 & 48 & -1.217 & NS \\
Majorca & 204 & -1.290 & NS \\
Minorca & 225 & -2.011 & $P<0.05$ \\
Total & 429 & -1.985 & $P<0.05$ \\
\hline
\end{tabular}

To test the relationship between the mtDNA haplotypes and nuclear markers, a set of cytonuclear disequilibria analyses was made with haplotypes I and II. The analyses with the samples separated did not show any cytonuclear disequilibria. All the samples were analysed as a unique population, because of the genetic similarity of the seven samples studied at the enzymatic level (with the exception of $A c p h-1$ ). Only a slightly significant cytonuclear disequilibrium was detected $\left(\chi_{1}^{2}=4.85\right)$ in the cytonuclear estimator of nuclear heterozygotes versus mtDNA haplotypes of Acph-2. Apart from this, no other cytonuclear disequilibrium estimator was significant in any enzyme.

\section{Discussion}

We have carried out an extensive study of seven samples of D. subobscura from the islands of Majorca and Minorca at the allozymic and mtDNA level. At the allozymic level we did not observe any clear genetic differentiation among the samples. Although the $F_{\mathrm{ST}}$ values were statistically significant, the tests of paired genetic differentiation did not show great differences between the samples. The only exception was when Acph-1 was included in the analyses, but this was caused by the different allozymic frequency of sample 2 from Minorca. Therefore, we consider that the populations of Majorca and Minorca have no clear genetic differences between them.

When the mtDNA was studied, the pattern agreed with that found in other populations, that is, I and II are present in all populations at high frequencies, whereas certain rare ones occur at low frequencies. The test we used to determine the average number of substitutions per nucleotide per pair of random haplotypes within and between populations (Lynch \& Crease, 1990) was not significant, which indicates that there is no betweenpopulation heterogeneity. This result is similar to that reported by González et al. (1994) in D. subobscura or by Baba-Aissa et al. (1988) and Nigro (1988) for D. simulans.

The mtDNA polymorphism observed in natural populations can be interpreted in several ways, such as interactions with nuclear polymorphisms, random genetic drift, or direct selection on the mtDNA 
haplotypes (Latorre et al., 1992; Moya et al., 1993; García-Martínez et al., 1998). The $D$-values of the Tajima test for mtDNA non-neutral evolution were not significant in the seven samples. Nevertheless, we detected significant negative $D$-values for the entire Minorcan population and the total population. According to Tajima (1989), a significant negative value might be the result of purifying selection or a population bottleneck. Although purifying selection might generate a negative $D$-value, it would be expected to be observed more significantly in all the populations analysed and this was not the case in our study. Therefore, we think that the explanation based on a population bottleneck is more acceptable. It is possible that the Minorcan population as a whole may not yet have reached equilibrium, probably as a consequence of seasonal periodic bottlenecks, followed by an expansion. The result would be an excess of rare haplotype polymorphism while the population was expanding. On the contrary, the Majorcan population seems to be more stable. The significance of the total population would be the result of the influence of the Minorcan population.

Cytonuclear associations between nuclear markers and mtDNA haplotypes or some kind of genetic hitchhiking are difficult to detect by means of cytonuclear disequilibria parameters. Unless fitness interactions are extremely strong, the disequilibrium parameters are quickly going to be negligible (Babcock \& Asmussen, 1996). Only some transient disequilibria could be expected as a consequence of genetic hitchhiking, and with adaptive markers, such as inversions, for example. In our case, the disequilibrium associated with Acph-2 could represent a transient disequilibrium established at the moment the samples were taken.

Because of the adaptive value of the inversions, experiments in population cages (i.e. a new environment different from that of nature) might generate strong genetic hitchhiking on different and neutral competing haplotypes. The detection of these associations could help us to understand the dynamics of mtDNA polymorphism in natural populations of this species.

\section{Acknowledgements}

This work has been supported by grants PB93-0690 and PB96-0793 from DGES (Spain).

\section{References}

AFONSO, J. M., VOLZ, A., HERNÁNDEZ, M., RUTTKAY, H., GONZÁLEZ, A. M., LARrUGA, J. M. ET AL. 1990. Mitochondrial DNA variation and genetic structure in Old-World populations of Drosophila subobscura. Mol. Biol. Evol., 7, 123-42.
ASMUSSEN, M. AND BASTEN, C. J. 1994. Sampling theory for cytonuclear disequilibria. Genetics, 138, 1351-1363.

AYALA, F. J., POWELl, J. R., TRACEY, M. L., MOURÃO, C. A. AND PÉREZ-SALAS, S. 1972. Enzyme variability in the Drosophila willistoni group. IV. Genic variation in natural populations of Drosophila willistoni. Genetics, 70, 113-139.

BABA-AISSA, F., SOLIGNAC, M., DENNEBOUY, N. AND DAVID, J. R. 1988. Mitochondrial DNA variability in Drosophila simulans: quasi-absence of polymorphism within each of the three cytoplasmic races. Heredity, 61, 419-426.

BABCOCK, C. S. AND ASMUSSEN, M. A. 1996. Effects of differential selection in the sexes on cytonuclear polymorphism and disequilibria. Genetics, 144, 839-853.

BREWER, G. J. 1970. An Introduction to Isozyme Techniques. Academic Press, New York.

CABrerA, V. M., GONZÁlez, A. M. AND GULlóN, A. 1980. Enzymatic polymorphism in Drosophila subobscura populations from the Canary islands. Evolution, 34, 875-887.

CLARY, D. O. AND WOLSTENHOLME, D. R. 1985. The mitochondrial DNA molecule of Drosophila yakuba: nucleotide sequence, gene organization, and genetic code. J. Mol. Evol., 22, 252-271.

FOS, M., DOMíngueZ, M. A., LATORRe, A. AND MOYA, A. 1990. Mitochondrial DNA evolution in experimental populations of Drosophila subobscura. Proc. Natl. Acad. Sci. U.S.A., 87, 4198-4201.

GARcía-MARTínez, J., CASTRO, J. A., RAMON, M. M., LATORRe, A. AND MOYA, A. 1998. Mitochondrial DNA haplotype frequencies in natural and experimental populations of Drosophila subobscura. Genetics, 149, 1377-1382.

GONZÁlEZ, A., CARRIó, R., FERNÁNDEZ-PEDROSA, V. AND MOYA, A. 1994. Lack of seasonal changes in mitochondrial DNA variability of a Drosophila subobscura population. J. Evol. Biol., 7, 29-38.

HUTTER, C. M. AND RAND, D. M. 1995. Competition between mitochondrial haplotypes in distinct nuclear genetic environments: Drosophila pseudoobscura vs. D. persimilis. Genetics, 140, 537-548.

KILPATRICK, S. T. AND RAND, D. M. 1995. Conditional hitchhiking of mitochondrial DNA: frequency shifts of Drosophila melanogaster mtDNA variants depend on nuclear genetic background. Genetics, 141, 1113-1124.

LATORRe, A., MOYA, A. AND AYALA, F. J. 1986. Evolution of mitochondrial DNA in Drosophila subobscura. Proc. Natl. Acad. Sci. U.S.A., 83, 8649-8653.

LATORRe, A., HERNÁNDEZ, C., MARTíneZ, D., CASTro, J. A., RAMON, M. M. AND MOYA, A. 1992. Population structure and mitochondrial DNA gene flow in Old World populations of Drosophila subobscura. Heredity, 68, 15-24.

LYNCH, M. AND CREASE, T. J. 1990. The analysis of population survey data on DNA sequence variation. Mol. Biol. Evol., 7, 377-394.

MACRAE, A. F. AND ANDERSON, w. W. 1988. Evidence for nonneutrality of mitochondrial DNA haplotypes in Drosophila pseudoobscura. Genetics, 120, 485-494.

MENOZZI, P. AND KRIMBAS, C. B. 1992. The inversion polymorphism of D. subobscura revisited: synthetic maps of gene arrangement frequencies and their interpretation. J. Evol. Biol., 5, 625-641. 
MOYA, A., BARRIO, E., MARTÍNEZ, D., LATORRE, A., GONZÁLEZCANDELAS, F., RAMON, M. M. ET AL. 1993. Molecular characterization and cytonuclear disequilibria of two Drosophila subobscura mitochondrial haplotypes. Genome, 36, 890-898.

NIGRO, L. 1988. Natural populations of Drosophila simulans show great uniformity of the mitochondrial DNA restriction map. Genetica, 77, 133-137.

ORENGO, D. J. AND PREvosti, A. 1996. Temporal changes in chromosomal polymorphism of Drosophila suobobscura related to climatic changes. Evolution, 50, 1346-1350.

PINSKER, W., LANKINEN, P. AND SPERLICH, D. 1978. Allozyme and inversion polymorphism in a central European population of Drosophila subobscura. Genetica, 48, 207-214.

RoZAS, J., HERnÁNDEZ, M., CABrerA, v. M. AND PREVOSTI, A. 1990. Colonization of America by Drosophila subobscura: effect of the founder event on the mitochondrial DNA polymorphism. Mol. Biol. Evol., 7, 103-109.

SWOFFORD, D. L. AND SELANDER, R. B. 1989. BIOSYS-1. A computer program for the analysis of allelic variation in population genetics and biochemical systematics. Release 1.7. University of Illinois, Urbana, IL.

TAJIMA, F. 1989. Statistical method for testing the neutral mutation hypothesis by DNA polymorphism. Genetics, 123, $585-595$.

WeIR, B. S. 1990. Genetic Data Analysis. Sinauer Associates, Sunderland, MA.

WRIGHT, S. 1965. The interpretation of population structure by $F$-statistics with special regard to systems of mating. Evolution, 19, 395-420. 